\title{
Alcohol Policy Compliance among retailers in Bhutan: A multisite community intervention study
}

Tshewang Gyeltshen ( $\nabla$ tgyeltshen09@gmail.com )

Tsirang Hospital

\section{Tshering Penjor}

Tsirang Hospital

Lham Dorji

Tsirang Hospital

\section{Lobzang Tshering}

Tsirang District Administration

\section{Kinley Kinley}

Tsirang Hospital

\section{Kinley Dorji}

Pema Gatshel Hospital

\section{Bhim Nath Subedi}

Pema Gatshel Hospital

\section{Dorji Tshering}

Gelephu Central Regional Referral Hospital, Gelephu, Bhutan

\section{Dil Kumar}

Yvonne Yiru Xu

World Health Organization Regional Office for South-East Asia

\section{Gampo Dorji}

World Health Organization Regional Office for South-East Asia

\section{Ghislain Gueye8}

Louisiana Tech University

\section{Research Article}

Keywords: Alcohol, Bhutan, Compliance, proxy purchase

Posted Date: March 10th, 2021

DOI: https://doi.org/10.21203/rs.3.rs-306506/v1

License: (c) (1) This work is licensed under a Creative Commons Attribution 4.0 International License. Read Full License 


\section{Abstract}

Alcohol use is a major public health problem in Bhutan. Compliance with regulations at point of sales is an important strategy in alcohol control. Retail outlets were briefed on sales regulations and provided notification with rules and directed to display in the premises. The extent to which licensed alcohol outlets responded to possible alcohol purchase was assessed through the use of young proxy-purchasers, adults feigning alcohol intoxicated and sober adults. A total of 854 visits (pre versus post visits) were made across four district towns. Two towns (Damphu town in Tsirang district and Pema Gatshel town in Pema Gatshel district) received pre- and post-intervention purchase surveys while other two neighboring towns (Khuruthang town in Punakha and Bajo town in Wangdue) were administered only baseline surveys.

Results: Retailers rarely checked the age and/or identification (ID) of the proxy-purchasers before the intervention. There was $22.7 \%(8.6,37)$ percent increase in compliance with laws after the intervention. While some strategies are suggested, the strongest and most effective measure to prevent under-age drinking and over service to intoxicated, more rigorous enforcement of existing liquor laws are required.

Conclusion: Alcohol control requires ongoing government enforcements supplemented by public awareness and knowledge.

\section{Background}

Alcohol use is a major public health problem globally. In Bhutan, alcohol-related liver disease is the number one cause of mortality accounting for $11 \%$ of the total deaths that occurred in health facilities in $2019^{1}$. Mortality is even higher after accounting for alcohol-related deaths due to heart disease, stroke, injuries, road traffic deaths, suicides and road traffic crashes.

Drinking is pervasive in Bhutanese society, and most drinkers start at an early age. One third (33.1\%) of adult Bhutanese are current drinkers (last 30 days) ${ }^{2}$ which is higher compared to figures in neighbouring countries (Nepal 18\%, Myanmar $20 \%$ and Sri Lanka $18 \%$ and India 11\%). Alcohol consumption is also highly prevalent among young people. A Bhutan schoolbased survey conducted in 2016 found that $24 \%$ of Bhutanese students below 18 years of age were current drinkers compared to their counterparts in Nepal (5.5\%); Myanmar (4.7\%) and Sri Lanka (3.2\%) ${ }^{3}$. Among underage students, $16.2 \%$ of females were current users in Bhutan contrary to other countries in South -East Asia where consumption among females is negligible ${ }^{4}$. Nearly $17 \%$ of the Bhutanese population (half of all current drinkers) are heavy episodic drinkers ${ }^{5}$. Four percent of the population reported needing their first drink in the morning indicating alcohol dependance ${ }^{5}$. Addition to ill health, excessive drinking has significant social and economic consequences ${ }^{6}$.

Bhutan has a comprehensive set of alcohol laws which include restriction of sales and supply to those under the age of 18; restriction of sales to alcohol-intoxicated individuals; prohibition of alcohol sales before 1 p.m. and after 10 p.m. Alcohol sales is prohibited on Tuesday, and drink driving regulated at blood alcohol level of $0.8 \%$ and $0 \%$ for commercial drivers ${ }^{7}$. Aside from the drink driving laws, enforcement of alcohol sales regulations is perceived to be poorly enforced which allows alcohol to be easily accessible during non-legal hours/day, and for any customer irrespective of age and intoxication level. A study conducted in 2013 by Dorji et al. documented widespread breach of the practices in sales and supplies of alcohol in premises in the capital city of Thimphu ${ }^{8}$.

Educating alcohol retailers on the alcohol sales requirements and legal consequences of violations combined with presence of enforcement is known to improve retailer's compliance ${ }^{8}$.

This study aimed to: (1) assess current levels of compliance with alcohol sales regulation in four townships in Bhutan, (2) evaluate the effect of alcohol legal information education and enforcement intervention(3) assess factors associated with compliance of legal alcohol sales amongst licensed retailers. 


\section{Methodology}

\section{Evaluation design}

We used a pre-and post-test community intervention design covering all alcohol retailers both on premise (bar, hotel, restaurant, karaoke bars) and off-premise (grocery shops). All establishments that had alcohol sales permits were selected from four district towns: Pema Gatshel town in Pema Gatshel district in the east, Damphu town in Tsirang district in the central and adjoining Khuruthang town in Punakha district and Bajo town in Wangdue district in the western region. The four districts were selected to represent the three geographical administrative regions commonly used as a reference in the country.

\section{Proxy Purchasers}

Outlets' willingness to sell alcohol was assessed using proxy purchasers comprising underage-looking purchasers $(<18$ years), sober adults and adults acting alcohol intoxicated. Four underage-looking young adults ( 2 females and 2 males) and 4 adults ( 2 females and 2 males) were recruited in Damphu town. In Pema Gatshel town, six purchasers - two underagelooking young adults ( 2 females and 2 males) and 4 adults ( 2 females and 2 males) were recruited. In Bajo and Khuruthang towns, eight underage-looking purchasers ( 2 females and 6 males) and eight adult purchasers were recruited. Purchasers were recruited based on the acting skills. Under-age looking young adults were identified as below 18 years by a group of judges. Proxy purchasers were trained on survey instruments using purchasing scenarios. The duration of training varied from two days in Damphu town to three hours training in Pema Gatshel, and one day for Bajo and Khuruthang towns. The same purchasers completed the purchase surveys in Bajo and Khuruthang. Separate group of purchasers were recruited in pre- and -post intervention purchase surveys in intervention districts of Pema Gatshel town and Damphu town.

The proxy clients attempted purchase at illegal hours (before $1 \mathrm{pm}$ during non-dry days); during dry day (Tuesday) and during legal hours (1-10 pm on a non-dry day) for underage looking and pseudo intoxicated adults. Legal visits between 110 p.m. by sober adults were included for comparison too. Every purchase attempt was made by a pair of proxy clients. After leaving the establishment, the purchasers were required to report to an enumerator who waited at a distance. The enumerator filled the survey tool as reported by the purchasers in their presence. Pre-intervention purchases were conducted in August 2019 and post-intervention purchase surveys in March 2020. Only pre-intervention purchase surveys were completed in Bajo and Khuruthang for baseline data acquisition.

\section{Intervention}

The intervention consisted of a briefing of outlet owners and sellers explaining the alcohol sales rules, and warning of the legal consequences of breach of alcohol rules by the government officers. The briefing was led by the Dzongdag (district governor), police officer, trade officer and district health officer. One representative from each retail outlet was invited from the study sites. The briefing was conducted on 29 October 2019 in Damphu and 10 October, 2019 in Pema Gatshel town. Briefing included existing alcohol sales rules, penalties and possible charges for violators, and the negative health effects of alcohol. The alcohol regulation toolkit containing information on sales rules and a copy of the laminated A3-size alcohol rules notification was handed over by the governor and officials and sellers were asked to display the notification in a prominent location within the premise. Retailers were informed that surprise checks will be conducted, and violators penalized as per the regulations that involve court hearings if required.

\section{Ethics approval}

Ethics approval was obtained from the Research and Ethics Board of the Ministry of Health, Royal Government of Bhutan for purchase surveys in Damphu and Pema Gatshel towns and local administrative approvals were obtained for Tsirang and Pema Gatshel district administrations. Wangdue and Punakha purchase attempts were done as a part of the routine monitoring activity of the chief medical officer at Bajo hospital and no ethical approval were sought. 


\section{Sampling}

All establishments with alcohol sales licenses (i.e. bars, hotels, restaurants, grocery, karaoke bars) in Damphu and Pema Gatshel towns and Bajo and Khuruthang were included for the study. A total of 60 outlets in Damphu and 12 outlets in Pema Gatshel town were provided with interventions while 55 outlets in Bajo and Khuruthang were included in the purchase survey(Table1.1)

Table1.1 Study design - Number of purchases made by shopper type and time/day of purchase

\begin{tabular}{|c|c|c|c|c|c|c|c|c|c|c|c|c|c|}
\hline & & & ampht & town, Tsi & rang & & magat & $\begin{array}{l}\text { shel town, } \\
\text { Gatshel }\end{array}$ & Pema & Wang & $\begin{array}{l}\text { due (B } \\
\text { (Khu }\end{array}$ & $\begin{array}{l}\text { ajo) \& Pun } \\
\text { uthang). }\end{array}$ & lakha \\
\hline & & Time/ & day of & purchase & attemp & & Time/d & $\begin{array}{l}\text { ay of purc } \\
\text { attempt }\end{array}$ & nase & & $\begin{array}{r}\text { e/day } \\
\text { att }\end{array}$ & $\begin{array}{l}\text { of purcha } \\
\text { empt }\end{array}$ & \\
\hline & & & $1-$ & & & & $1-$ & & & & $1-$ & & \\
\hline tion & Shopper & before & 10 & & & before & 10 & & & before & 10 & & \\
\hline & type & 1 p.m. & p.m. & Tuesday & Total & 1 p.m. & p.m. & Tuesday & Total & 1 p.m. & p.m. & Tuesday & Total \\
\hline & Sober & & & & & & & & & & & & \\
\hline & adults & 53 & 0 & 40 & 93 & 5 & 7 & 10 & 22 & - & 3 & 103 & 106 \\
\hline & Intoxicated & & & & & & & & & & & & \\
\hline & adults & 4 & 54 & 0 & 58 & 0 & 12 & 0 & 12 & - & 36 & - & 36 \\
\hline & Underage & 7 & 51 & 0 & 58 & 0 & 11 & 0 & 11 & - & 49 & 29 & 78 \\
\hline & Total & 64 & 105 & 0 & 209 & 5 & 30 & 0 & 45 & - & 88 & 132 & 220 \\
\hline & Sober & & & & & & & & & & & & \\
\hline & adults & 24 & 24 & 49 & 97 & 24 & 24 & 49 & 97 & - & - & - & - \\
\hline & intoxicated & & & & & & & & & & & & \\
\hline & adults & 1 & 52 & 1 & 54 & 1 & 52 & 1 & 54 & - & - & - & - \\
\hline & Underage & 0 & 24 & 15 & 39 & 0 & 24 & 15 & 39 & - & - & - & - \\
\hline & Total & 25 & 100 & 65 & 190 & 25 & 100 & 65 & 190 & - & - & - & - \\
\hline
\end{tabular}

\section{Analysis}

The data was entered and managed using Epidata Entry Software version 3.1. A double entry was made and validated. Data analysis was carried out using Stata 15 IC (StataCorp. 2017. Stata Statistical Software: Release 15. College Station, TX: StataCorp LLC). Analysis included all completed purchase attempts which included illegal purchasing of alcohol of 4 different scenarios: (1) before 1 p.m., (2) on Tuesdays, (3) to underage-appearing patrons (i.e. younger than 18 years old), (4) to patrons who appeared to be intoxicated. While alcohol purchasing after 11 p.m. would be illegal, these purchasing attempts were not carried out as none of the outlets were open till 11 p.m. Few purchase attempts of sober adults during legal hours were completed too for comparison.

Information on main characteristics of sampled establishments were summarized. Primary outcome was compliance defined as failed purchase of illegal alcohol sales. Effect of the intervention on the difference of compliance rate to legal restriction was estimated using linear probability regression model. Both crude effect and adjusted effect were estimated for the full sample in Tsirang and Pema Gatshel. Effects were estimated for each purchaser scenario and two-way cluster was accounted for in the standard error at the level of the shopper and the establishment using Stata command ivreg2. To account for overlapping subgroups, (i.e. underaged shopper on Tuesday), each shopper type and time/day of attempt were included as covariates for each sub-group analysis. Finally, we identified predictors of compliance with alcohol service laws 
using a multi-variable logistic model. Multiple models with various predictors were tested and the final model was selected based on the lowest AIC score.

\section{Results}

When compared between pre- and post-interventions, there was increase in establishments that displayed signage of alcohol regulations, and those that displayed in prominent placement and even increase in display of smoking prohibition signage (Table 2) Characteristics in customer volume, servers', type, age and gender remained comparable the two purchase surveys. 
Table 2 Characteristics of completed mystery shopper purchase attempts (Damphu and Pema Gatshel only)

Pre-intervention (\%)

Total

Outlet type

Bar/ Karaoke Bars

Hotel/ Lodge

Restaurant

Grocery

Others

Overall condition of establishment

Good

Fair

Poor

Lighting of establishment

Poorly lit

Fairly Lit

Well Lit

\section{Server type}

Manager/owner

Waiter

Customer flow of establishment

Idle

Engaged but not busy

Very busy

Server position

Manager/Owner

Waiter

Server gender

Male

Female

Approximate server age

Above 30 years

Less than 30 years

Alcohol beverage asked for

Beer

Hard Drinks

Other

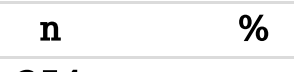

254

81

30

79

48

16

31.9

11.8

31.1

18.9

6.3
31.5

58.7

9.8

8.7

64.2

27.2

95.1

4.9

12

128

100

26

242

12

74

180

200

54

145

7

30

Post-intervention (\%)

N

234

91

38.9

5.6

25.2

22.2

8.1

$\%$

-

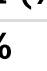

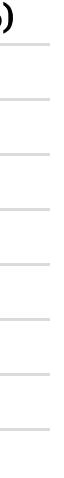




$\begin{array}{lcccc}\text { No } & 50 & 27.8 & 12 & 5.4 \\ \text { Yes } & 130 & 72.2 & 210 & 94.6 \\ \text { Nablishment displayed smoking prohibition signage } & & & & \\ \text { No } & 115 & 45.3 & 17 & 7.3 \\ \text { Yes } & 139 & 54.7 & 217 & 92.7\end{array}$

Failed purchase attempts (i.e. compliance with legal regulations) prior to intervention was poorest in Pema Gatshel town where all purchasing attempts were successful, and compliance was highest in Damphu town at $19.6 \%$. Compliance with restrictions of sales on Tuesday was relatively higher as compared to other types of scenarios, and lowest compliance was seen with intoxicated patrons.

\begin{tabular}{|c|c|c|c|c|c|c|c|c|}
\hline \multirow[t]{2}{*}{ Region } & \multicolumn{2}{|c|}{ Damphu, Tsirang } & \multicolumn{2}{|c|}{ Pema Gatshel } & \multicolumn{2}{|c|}{ Bajo/Khuruthang_ } & \multicolumn{2}{|c|}{ Total } \\
\hline & $\begin{array}{l}\text { Purchase } \\
\text { attempts }\end{array}$ & $\begin{array}{l}\text { Proportion } \\
\text { refused }\end{array}$ & $\begin{array}{l}\text { Purchase } \\
\text { attempts }\end{array}$ & $\begin{array}{l}\text { Proportion } \\
\text { refused }\end{array}$ & $\begin{array}{l}\text { Purchase } \\
\text { attempts }\end{array}$ & $\begin{array}{l}\text { Proportion } \\
\text { refused }\end{array}$ & $\begin{array}{l}\text { Purchase } \\
\text { attempts }\end{array}$ & $\begin{array}{l}\text { Proportion } \\
\text { refused }\end{array}$ \\
\hline $\begin{array}{r}\text { Type of } \\
\text { purchase }\end{array}$ & & & & & & & & \\
\hline $\begin{array}{l}\text { Before } 1 \\
\text { p.m. }\end{array}$ & 64 & $17.2 \%$ & 5 & $0.0 \%$ & 2 & $50.0 \%$ & 71 & $16.9 \%$ \\
\hline Tuesday & 40 & $30.0 \%$ & 10 & $0.0 \%$ & 132 & $28.8 \%$ & 182 & $27.5 \%$ \\
\hline $\begin{array}{l}\text { Underage- } \\
\text { appearing } \\
\text { patrons } \\
\end{array}$ & 58 & $32.8 \%$ & 11 & $0.0 \%$ & 78 & $2.6 \%$ & 147 & $14.3 \%$ \\
\hline $\begin{array}{l}\text { Pseudo- } \\
\text { intoxicated } \\
\text { patrons }\end{array}$ & 58 & $5.2 \%$ & 12 & $0.0 \%$ & 36 & $2.8 \%$ & 106 & $3.8 \%$ \\
\hline $\begin{array}{r}\text { Full } \\
\text { sample }\end{array}$ & 209 & $19.6 \%$ & 38 & $0.0 \%$ & 217 & $18.9 \%$ & 474 & $17.3 \%$ \\
\hline
\end{tabular}

There was a statistically significant increase in refusal of alcohol purchase attempts by $22.7 \%$ overall and in all purchasing scenarios except for illegal purchasing before $1 \mathrm{pm}$. When disaggregated by purchasing scenario, increase in refusal was highest in the underage-appearing patron scenario. The same relationship remains after adjusting for other purchasing scenarios (Table 4). The change in the compliance rate for each purchase category and the adjusted effect estimates with a 95\% confidence interval are displayed in Figure 1 and Figure 2 respectively. 


\begin{tabular}{|c|c|c|c|c|c|c|c|c|}
\hline$\overline{\text { Compl }}$ & ce rate by & pe of pur & e and eff & estimates & Tsirang_and & ema & & \\
\hline & Pre-in & rvention & Post-in & rvention & $\begin{array}{r}\text { Unadjust } \\
\text { estim }\end{array}$ & $\begin{array}{l}\text { effect } \\
\text { tes }\end{array}$ & $\begin{array}{r}\text { Adjusted } \\
\text { estim }\end{array}$ & $\begin{array}{l}\text { effect } \\
\text { tes }\end{array}$ \\
\hline ;e & $\begin{array}{l}\text { Purchase } \\
\text { attempts }\end{array}$ & $\begin{array}{l}\text { Proportion } \\
\text { refused }\end{array}$ & $\begin{array}{l}\text { Purchase } \\
\text { attempts }\end{array}$ & $\begin{array}{l}\text { Proportion } \\
\text { refused }\end{array}$ & Difference & $95 \% \mathrm{CI}$ & Difference & $95 \% \mathrm{CI}$ \\
\hline 1 p.m. & 69 & $16 \%$ & 34 & $26 \%$ & $10.5 \%$ & $\begin{array}{l}(-6.4 \%, \\
27.5 \%)\end{array}$ & $11.8 \%$ & $\begin{array}{l}(-3.0 \% \\
26.6 \%)\end{array}$ \\
\hline $\bar{y}$ & 50 & $24 \%$ & 76 & $45 \%$ & $20.7 \%$ & $\begin{array}{c}(2.8 \% \\
39.7 \%)\end{array}$ & $19.3 \%$ & $\begin{array}{c}(1.1 \%, \\
37.5 \%)\end{array}$ \\
\hline $\begin{array}{l}\text { ge- } \\
\text { ng }\end{array}$ & 69 & $28 \%$ & 50 & $54 \%$ & $26.5 \%$ & $\begin{array}{l}(12.0 \%, \\
40.9 \%)\end{array}$ & $27.8 \%$ & $\begin{array}{l}(12.4 \%, \\
43.2 \%)\end{array}$ \\
\hline ted & 70 & $4 \%$ & 65 & $26 \%$ & $21.9 \%$ & $\begin{array}{l}(10.8 \%, \\
33.0 \%)\end{array}$ & $21.9 \%$ & $\begin{array}{l}(10.1 \%, \\
33.7 \%)\end{array}$ \\
\hline nple & 247 & $17 \%$ & 206 & $38 \%$ & $22.7 \%$ & $\begin{array}{c}(8.6 \%, \\
37.0 \%)\end{array}$ & - & - \\
\hline
\end{tabular}

Table 5 shows the adjusted odds ratios of the predictors that are associated with refusal of purchase attempts in two models. Receipt of intervention was a statistically significant predictor for purchase refusal in model 1. However, this relationship became insignificant after adjusting for establishments that displayed signage of alcohol prohibition which was given out as part of the alcohol toolkit during the intervention. Establishments where any type of signage relating to alcohol prohibition was displayed were 3.0 times more likely to refuse alcohol sales (OR:3.01, 95\% Cl: 1.67-5.36). Restaurants were twice more likely to comply with alcohol sales restrictions compared to Bars/ Karaoke bars (OR: 2.22, 95\% $\mathrm{Cl} 1.23-3.99$ ). Establishments that are very busy were significantly less likely to comply with prohibition than those that were idle (OR:0.15, $95 \% \mathrm{Cl}: 0.05-0.46)$. Figures 3 and 4 are forest plots of the odds ratios with a 95\% confidence interval for model 1 and 2 , respectively. 
Table 5 Predictors for compliance with alcohol purchasing regulations

\begin{tabular}{|c|c|c|c|c|c|c|c|c|c|c|}
\hline \multirow{3}{*}{ Post intervention (compared to pre) } & \multicolumn{5}{|c|}{ Model 1} & \multicolumn{5}{|c|}{ Model 2} \\
\hline & \multirow{2}{*}{$\begin{array}{l}\text { OR } \\
3.98\end{array}$} & \multirow{2}{*}{$\begin{array}{l}\text { SE } \\
1.00\end{array}$} & \multirow{2}{*}{$\begin{array}{l}\mathbf{p}- \\
\text { value } \\
0.00\end{array}$} & \multicolumn{2}{|c|}{$95 \% \mathrm{CI}$} & \multirow{2}{*}{$\begin{array}{l}\text { OR } \\
1.66\end{array}$} & \multirow{2}{*}{$\begin{array}{l}\text { SE } \\
0.54\end{array}$} & \multirow{2}{*}{$\begin{array}{l}\text { p- } \\
\text { value } \\
0.12\end{array}$} & \multicolumn{2}{|c|}{$95 \% \mathrm{CI}$} \\
\hline & & & & 2.44 & 6.51 & & & & 0.87 & 3.13 \\
\hline Legal purchase & 1.49 & 0.64 & 0.36 & 0.64 & 3.48 & 2.10 & 1.08 & 0.15 & 0.77 & 5.73 \\
\hline \multicolumn{11}{|l|}{ Outlet type } \\
\hline Bars/Karaoke & 1.00 & - & - & - & - & 1.00 & - & - & - & - \\
\hline Hotel/lodge & 1.99 & 0.85 & 0.11 & 0.86 & 4.62 & 1.76 & 0.82 & 0.23 & 0.70 & 4.38 \\
\hline Restaurant & 2.12 & 0.59 & 0.01 & 1.22 & 3.66 & 2.22 & 0.66 & 0.01 & 1.23 & 3.99 \\
\hline Grocery & 0.81 & 0.27 & 0.53 & 0.42 & 1.56 & 0.55 & 0.21 & 0.13 & 0.26 & 1.18 \\
\hline Other & 1.12 & 0.53 & 0.81 & 0.44 & 2.82 & 1.44 & 0.80 & 0.52 & 0.48 & 4.26 \\
\hline \multicolumn{11}{|l|}{ Server position } \\
\hline Manager/Owner & 1.00 & - & - & - & - & 1.00 & - & - & - & - \\
\hline Waiter & 1.07 & 0.52 & 0.90 & 0.41 & 2.79 & 0.94 & 0.49 & 0.91 & 0.34 & 2.62 \\
\hline \multicolumn{11}{|l|}{ Sex of server } \\
\hline Male & 1.00 & - & - & - & - & 1.00 & - & - & - & - \\
\hline Female & 1.80 & 0.49 & 0.03 & 1.05 & 3.08 & 1.69 & 0.51 & 0.08 & 0.94 & 3.05 \\
\hline \multicolumn{11}{|l|}{ Suspected age of server } \\
\hline 30 and over & 1.00 & - & - & - & - & 1.00 & - & - & - & - \\
\hline Less than 30 & 1.08 & 0.33 & 0.81 & 0.59 & 1.98 & 0.92 & 0.31 & 0.79 & 0.48 & 1.76 \\
\hline \multicolumn{11}{|l|}{ Alcohol beverage asked for } \\
\hline Beer & 1.00 & - & - & - & - & 1.00 & - & - & - & - \\
\hline Hard Drinks & 1.91 & 0.51 & 0.02 & 1.13 & 3.23 & 1.72 & 0.50 & 0.06 & 0.97 & 3.04 \\
\hline Other & 1.10 & 0.36 & 0.77 & 0.58 & 2.09 & 1.04 & 0.35 & 0.90 & 0.54 & 2.03 \\
\hline \multicolumn{11}{|l|}{ Customer flow of establishment } \\
\hline Idle & 1.00 & - & - & - & - & 1.00 & - & - & - & - \\
\hline Engaged but not busy & 0.57 & 0.14 & 0.02 & 0.36 & 0.91 & 0.68 & 0.18 & 0.13 & 0.40 & 1.13 \\
\hline Very busy & 0.12 & 0.07 & 0.00 & 0.04 & 0.36 & 0.15 & 0.09 & 0.00 & 0.05 & 0.46 \\
\hline \multicolumn{11}{|l|}{ General condition of establishment } \\
\hline Good & 1.00 & - & - & - & - & 1.00 & & & & \\
\hline Fair & 1.39 & 0.46 & 0.32 & 0.73 & 2.65 & 1.63 & 0.60 & 0.19 & 0.79 & 3.36 \\
\hline Poor & 0.87 & 0.57 & 0.84 & 0.24 & 3.17 & 1.52 & 1.11 & 0.57 & 0.36 & 6.37 \\
\hline \multicolumn{11}{|l|}{ Lighting of establishment } \\
\hline Poorly lit & 1.00 & - & - & - & - & 1.00 & - & - & - & - \\
\hline Fairly Lit & 1.03 & 0.54 & 0.95 & 0.37 & 2.90 & 2.41 & 1.70 & 0.21 & 0.61 & 9.60 \\
\hline Well Lit & 1.35 & 0.81 & 0.62 & 0.42 & 4.35 & 2.74 & 2.12 & 0.20 & 0.60 & 12.52 \\
\hline \multicolumn{11}{|l|}{$\begin{array}{l}\text { Establishment displayed any type of } \\
\text { alcohol prohibition signage }\end{array}$} \\
\hline No & - & - & - & - & - & 1.00 & - & - & - & - \\
\hline Yes & - & - & - & - & - & 3.01 & 0.89 & 0.00 & 1.69 & 5.36 \\
\hline \multicolumn{11}{|l|}{ Placement of signage was prominent } \\
\hline No & - & - & - & - & - & 1.00 & - & - & - & - \\
\hline Yes & - & - & - & - & - & 0.75 & 0.44 & 0.63 & 0.24 & 2.38 \\
\hline $\begin{array}{l}\text { stablishment displayed } \\
\text { rohibition signage }\end{array}$ & & & & & & & & & & \\
\hline
\end{tabular}




\section{Discussions}

This is the first multisite study to date conducted in Bhutan to assess alcohol retail establishments' compliance to alcohol sales regulation along with applying educational interventions to improve policy knowledge amongst retailers through organized training sessions. The baseline refusal rate in the four districts was very low (17.3\%) which indicates poor compliance to alcohol sales rules and regulations at the point of sales. The compliance of Tuesdays (27.5\%) as dry days was most noticeable while sales to intoxicated adults (3.8\%) were least compliant suggesting possible lack of knowledge on alcohol regulations. This gap was largely improved post intervention which suggests that educational intervention and enforcement portrayal were effective. More concerning, compliance to denying sales to under-aged purchasers was only $14.3 \%$ at baseline. This would probably explain the high prevalence of alcohol use in Bhutan amongst those under 18 years of age $\mathrm{e}^{3}$.

Of the four districts with baseline comparison, Pema Gatshel performed worst in baseline refusal rate $(0.0 \%)$ although due low number of purchase attempts, it is difficult to be conclusive. Damphu performed well in refusal to under aged patrons compared to other regions (32.8\%). The intervention was effective in improving overall refusal rate with the most prominent improvements for underage patrons (53.9\%). No effects of the interventions were seen for restrictions of alcohol sales before 1 p.m. which may reflect implementation and pragmatic challenges for establishments to comply with. We speculate it is simply easier to refuse customers on an entire day such as Tuesday rather than restricting to specific hours in a day. Further qualitative data may be helpful to better understand how such policies influence sellers' behaviors.

Our analysis shows that displaying signage of alcohol prohibition in the store was predictive of compliance. There may be two explanations to this finding. First this could suggest that requiring signage placement is an effective policy tool to ensure legal compliance with alcohol restrictions and should be made mandatory with sufficient enforcement. Second, the association noted here maybe a proxy to the diligence and compliance of the establishment of itself rather than due to the visible signaling of a signage. We are unable to draw conclusions here as we cannot draw causation from display of signage based on our analysis.

In finding that busier establishments are less likely to comply is concerning. This suggests underlying lack of diligence where the importance of complying with alcohol restriction is overlooked or not in the forefront of the minds of the server. Police enforcement and checks may resolve this concern. If owners are aware that random checks can be made and they would suffer repercussions such as paying a fine, then even amidst busy service times, legal compliance with the law comes to the forefront of one's mind. Police enforcement should also consider conducting checks at peak hours.

These findings are consistent with the earlier study done in Thimphu, the capital city of Bhutan ${ }^{9}$.

Compared to the previous study ${ }^{8}$, this study had a larger reduction in intervention effect. However, absolute compliance postintervention remains low at 38\% compared to $34 \%$ in the last study which also had an enforcement component. The post intervention change is lower than we anticipated. Part of the study interventions coincided with the early phase of the COVID19 pandemic in 2020. The enforcement visits were not conducted per protocol as initially designed which may explain for lower effect. This indicates that legal education, training alone will not reach optimal levels of legal compliance. There may be gaps in educational training methods that could improve seller's awareness; room for increasing legal repercussion such as increasing fines and penalties.

Bhutan with abundant access to alcohol ${ }^{10}$ being freely available both off premise and on premise outlets needs strong law enforcements. The alcohol laws are being violated without regard as evidenced from our findings and previous findings. 
Substantial gaps remain in improving legal compliance of alcohol laws in Bhutan.

Future research should focus on evaluating the effectiveness of different components of the education interventions in terms of its content as well as hand-out materials such as signages. Established perceptions of alcohol regulation should be better researched to understand potential drivers and barriers to compliance at point-of-sale.

Our study also has several limitations. The study is subjected to the concerns of the ecological fallacy. We did not have any control district to adjust for possible external factors that may explain the increase in compliance to alcohol regulations. Therefore, we cannot state that the increase of compliance solely caused by the education interventions itself. Second, the sample size is relatively small compared to other studies. However, Bhutan is not a densely populated country and thus, what is sampled is inclusive of all establishments within selected district towns. Finally, our study evaluated the effects 5-month post intervention. Without sustained enforcement and education, the effects may dissipate overtime.

\section{Conclusion}

Alcohol control requires ongoing government enforcements supplemented by public awareness and knowledge. Our study demonstrated despite long-standing alcohol sales regulation in Bhutan, the compliance at point-of-sale was low across all districts. The effectiveness of the policy of alcohol sales restriction before 1p.m. is low and warrants further review or replacement of more effective alternatives. Moreover, education activities should be conducted periodically and possibly should be included as part of alcohol sales permit renewal requirements to ensure establishment awareness over time and sustained effects of the intervention. Furthermore, if local law enforcement wants to conduct random compliance checks, surveillance during peak alcohol sales hours would be appropriate. Current poor compliance not only results in large socioeconomic costs, it also at the cost of the future of the most vulnerable portion of the population - children and adolescents.

\section{Declarations}

\section{Acknowledgements}

The authors thank the Ministry of Health, Royal Government of Bhutan and the WHO, SEARO office, New Delhi for technical and financial support. We also thank all the research assistants for their valuable contribution to the data collection.

\section{Ethics Approval and Consent to participate}

Ethics approval has been approved by the Research Ethics Board of Health (REBH), Ministry of Health, Royal Government of Bhutan vide approval number Ref. No. REBH/Approval/2019/004.

Consent for Publication: All authors have read the manuscript and consented to publication.

\section{Availability of Data and Materials}

Data and materials available with the corresponding author upon request.

\section{Competing Interest: None}

Funding: Not Applicable

\section{Authors Contribution}

TG: Principal Investigator and corresponding author, conception / design of the protocol, acquisition of data, data analysis / interpretation, manuscript drafting / critically reviewing the paper, giving approval for the final version to be published. 
GD: Conception / design of the protocol, data analysis / interpretation, manuscript drafting/critically reviewing the paper and giving approval for the final version to be published.

YX: Data analysis / interpretation, critically reviewing the paper and giving approval for the final version to be published.

GG: Data analysis / interpretation, critically reviewing the paper and giving approval for the final version to be published.

LD, TP, LT, K, KD, BNS, DT \& DK: Acquisition of data, critically reviewing the paper and giving approval for the final version to be published.

All Authors have reviewed the manuscript.

\section{References}

1. Government HR. People-centred Package of Essential Noncommunicable (PEN) disease health services in Bhutan Ministry of Health Royal Government of Bhutan. 2019;(February).

2. Noncommunicable Disease Risk Factors: Bhutan STEPS Survey Report, 2019.; 2019.

3. Thinley S. Report on Bhutan Global School-Based Student Health Survey.; 2016.

4. WHO. South-East Asia Region - Alcohol.; 1995.

5. Annual Health Bulletin-2020 Bhutan. Published online 2020.

6. National Statistics Bureau, Monograph Series LD. Alcohol Use and Abuse in Bhutan.; 2009.

7. Safty R, Authority T, Communications MOF, Government R. ROAD SAFETY AND TRANSPORT ACT 1999 ROAD SAFTY AND TRANSPORT AUTHORITY ROAD SAFTY AND TRANSPORT ACT - 1999. Published online 1999.

8. Dorji G. Promoting responsible alcohol service practices among licensed establishments in Thimphu, Bhutan : a pilot intervention. Published online 2014. http://open.bu.edu

9. Dorji G, Dejong W, Bor J, et al. Increasing compliance with alcohol service laws in a developing country: intervention trial in the Kingdom of Bhutan. Published online 2015:467-474. doi:10.1111/add.13202

10. Ministry of Health RG of B. Annual Report of the Ministry of Health, 2017.; 2017.

\section{Figures}

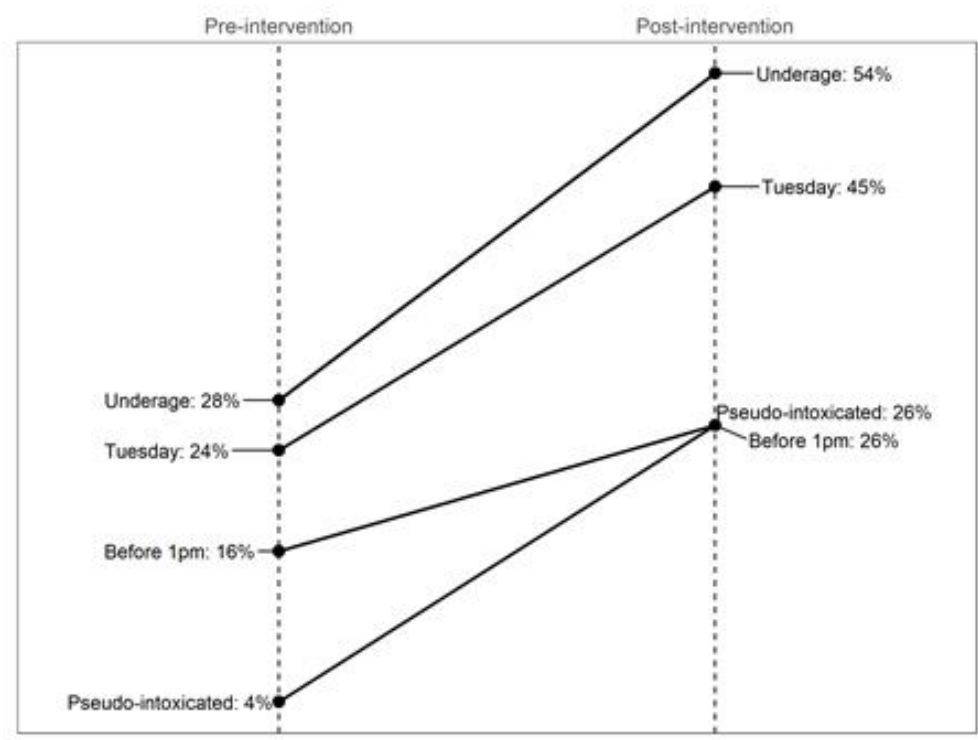

Page $12 / 14$ 


\section{Figure 1}

Impact of intervention on the compliance rate by purchase type

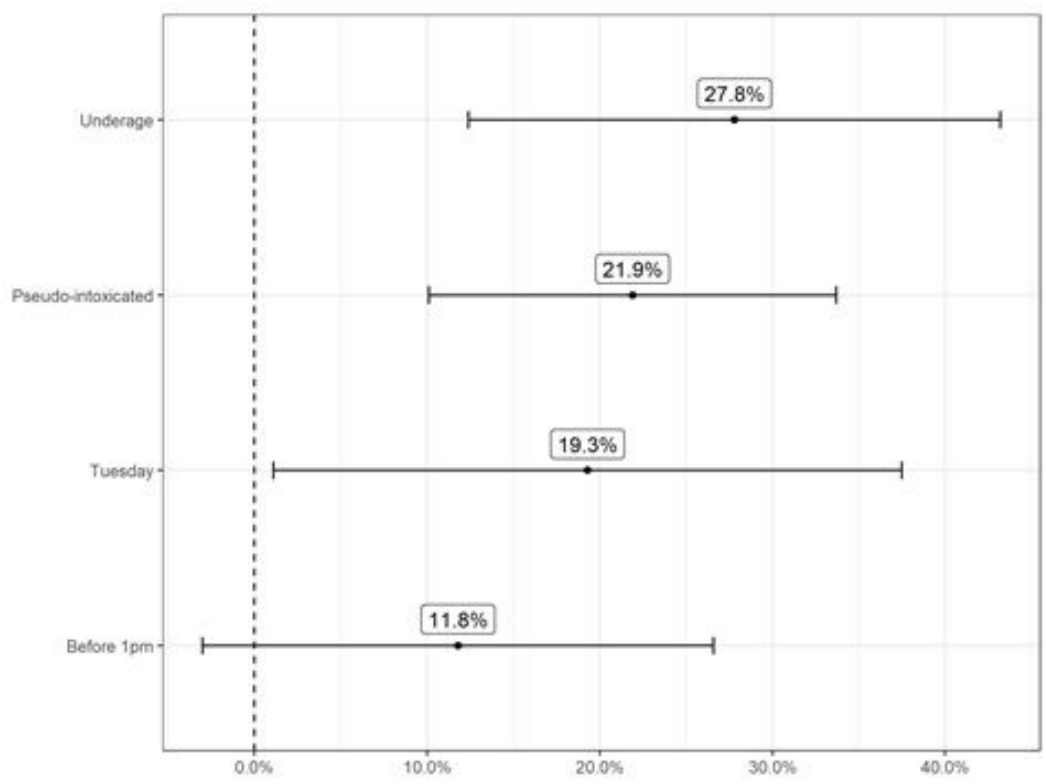

\section{Figure 2}

Adjusted effect estimates and $95 \% \mathrm{Cl}$ of intervention on the compliance rate by purchase type

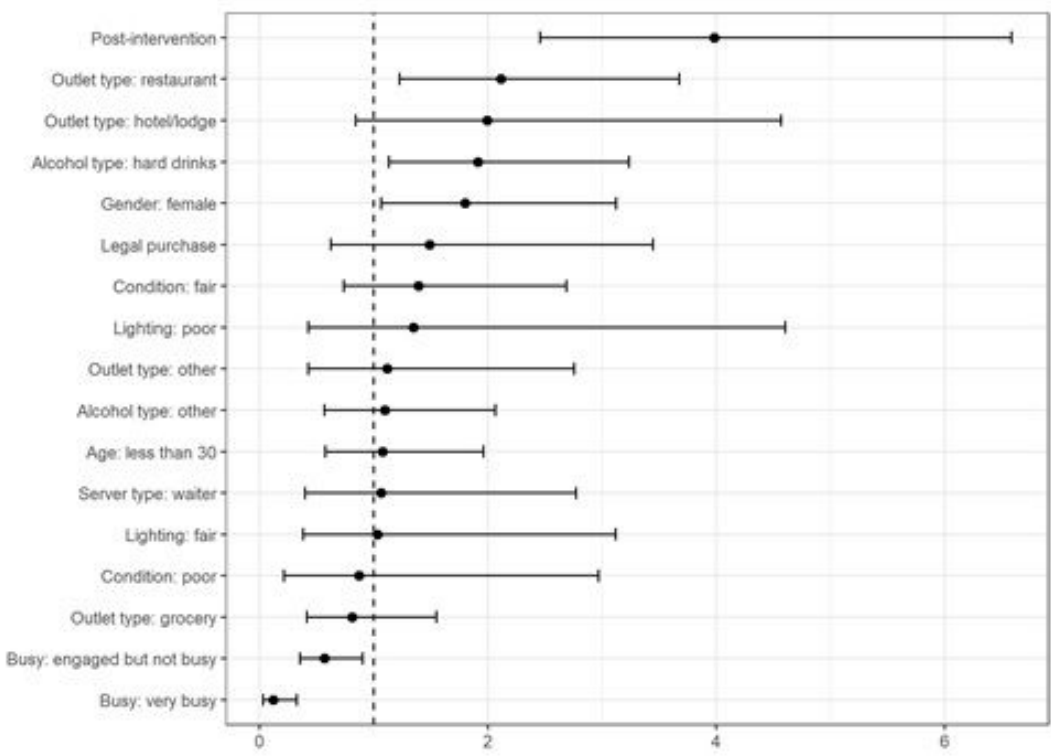

\section{Figure 3}

Model 1 odd ratios estimates and 95\% confidence interval 


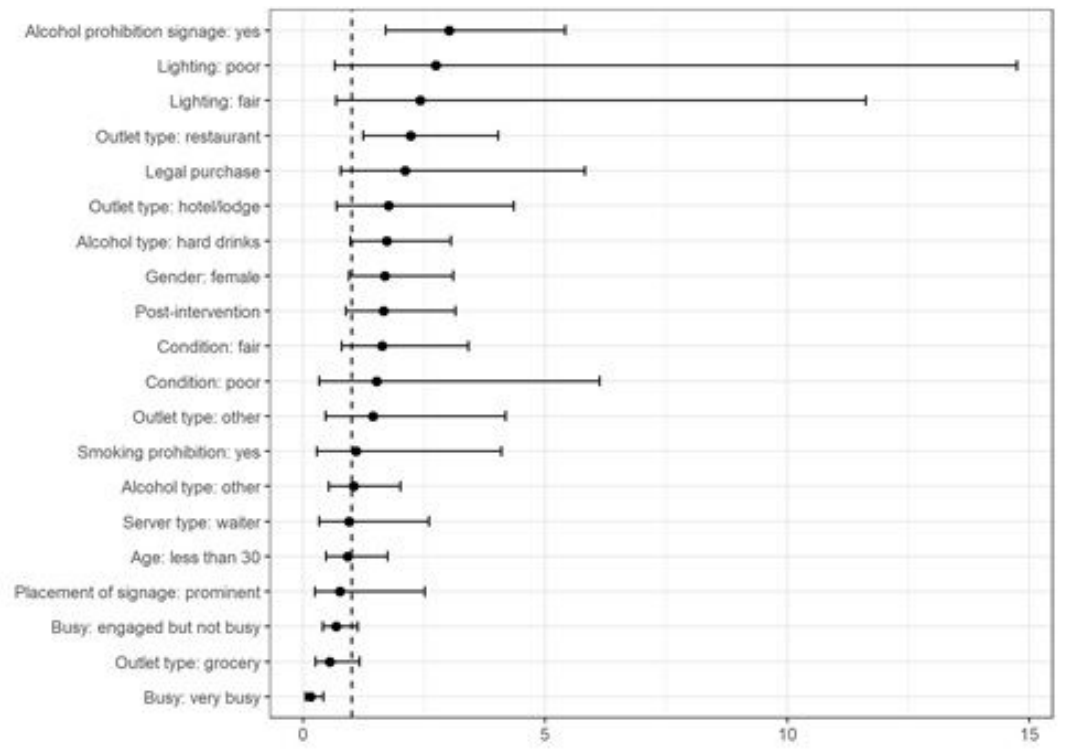

\section{Figure 4}

Model 2 odd ratios estimates and 95\% confidence interval 